\title{
Anthós
}

Volume 10 | Issue 1

Article 15

$6-21-2021$

\section{Impacts of COVID-19 on Rural Medical Business Models}

\author{
Kendra L. Stefan \\ Portland State University
}

Follow this and additional works at: https://pdxscholar.library.pdx.edu/anthos

Part of the Analytical, Diagnostic and Therapeutic Techniques and Equipment Commons, Health and Medical Administration Commons, Health Information Technology Commons, and the Public Health Commons

Let us know how access to this document benefits you.

\section{Recommended Citation}

Stefan, Kendra L. (2021) "Impacts of COVID-19 on Rural Medical Business Models," Anthós: Vol. 10: Iss. 1, Article 15.

https://doi.org/10.15760/anthos.2021.10.1.15

This open access Article is distributed under the terms of the Creative Commons Attribution-NonCommercialShareAlike 4.0 International License (CC BY-NC-SA 4.0). All documents in PDXScholar should meet accessibility standards. If we can make this document more accessible to you, contact our team. 


\title{
Impacts of Covid-19 on Rural Medical Business Models
}

\author{
Kendra L. Stefan
}

\section{Introduction ${ }^{1}$}

According to the Office of Disease Prevention and Health Promotion, one of the significant challenges in this country is adequate medical care access (ODPHP 2020). Even in a typical year, there are barriers: insufficient infrastructure; profit incentives over human need; professional shortages; and geographic, cultural, and economic disparities, to name but a few (ORH 2020). This paper will be looking at how COVID-19 impacts the medical delivery system in a rural community. I will review identified barriers to healthcare access and, under the pandemic's magnification, identify successes and new obstacles to overcome.

This study takes place in the rural community of Vernonia, Oregon. Vernonia is geographically isolated in Oregon's coastal mountain range, 35 miles from Scappoose and 37 miles from Hillsboro. In 1978 it was designated a Health Professional Shortage Area (HPSA), and this status was reconfirmed in 2017(ORH, 2020). In 1996 and 2007, the community was devastated by flooding resulting in the loss of schools and a medical clinic (Crenshaw, 2008). Immediately following each of these events, there was an exodus of community members. Residents cited the loss of these two institutions as decreasing the community's livability and their reason for leaving. The resulting educational and medical desert gave way to an economic downturn that took years to recover from. Community leaders learned lessons in 1996 that diminished this result in 2007 but did not eradicate it. Identified as fundamentally important to the community's sustainability, plans were to rebuild a single K-12 school and the medical clinic by early 2008. Still, they were not completed until 2010 (Oregon Solutions, 2008 and City of Vernonia, Flood Info 2010). Until then, temporary structures were erected to maintain continuity of services for the community. In 2010 the Federal Government designated Vernonia as a Medically Underserved Area (MUA) and a Physician Shortage Area (PSCA) (ORH, 2020).

During this recovery process, the $2009 \mathrm{H} 1 \mathrm{~N} 1$ pandemic hit and drew attention to preparedness planning. From the national and state levels down to the county and local community level, information was gathered, studied, and plans were put in place to prepare for a health crisis of pandemic proportions (Office of Government Accountability, 2011). The pandemic preparedness planning was done parallel to preparedness planning for natural disasters and domestic terrorism already underway in Vernonia and Columbia County. Having rebuilt

\footnotetext{
${ }^{1}$ This article, which was based on a class project rather than a research study, was not reviewed by the PSU IRB.
} 
from multiple natural disasters, it was understood that the protection of life and economic factors needed to be safeguarded. Columbia County Public Health and Columbia County Emergency Preparedness worked to develop a plan incorporating national and state guidelines and community-specific capacity concerns, infrastructure inventory, and strategic response (Columbia County, 2019).

On March 8, 2020, Governor Brown declared an emergency due to the public health threat posed by COVID-19. On March 12, 2020, she prohibited gatherings of 250 or more people and announced a statewide closure of Oregon K-12 schools. On March 13, 2020, the United States President declared the COVID-19 outbreak a national emergency. On March 17, 2020, Governor Brown prohibited gatherings of 25 or more people, banned on-site consumption of food and drink at food establishments statewide, and extended school closures. She also encouraged all businesses to implement social distancing protocols. On March 19, 2020, postponement of non-urgent health care procedures in order to conserve personal protective equipment was ordered. On March 24, 2020, Governor Brown issued Mandate 20-12 Stay Home-Save Lives order (Brown, 2020).

Columbia County identified its first Covid-19 case on March 27, 2020. The isolation of Vernonia delayed transmission, and the first documented case was reported on May 19, 2020 (OHA, 2020). Local businesses complied with Stay Home - Save Lives Mandate 20-12 as of March 24, 2020. This research project focused specifically on local rural medical delivery systems within this preparedness model. It evaluates the response to Covid-19 within a rural medical delivery system's constraints with a pandemic preparedness plan.

\section{Literature Review:}

The discourse community regarding pandemic preparedness in rural communities consists of predominantly public health specialists with backgrounds in epidemiology, infectious disease, health outcomes, and modeling. They have worked for WHO, the CDC, the National Academy of Medicine, Harvard, and various philanthropic health organizations focused on research.

The WHO commissioned a report on Pandemic Preparedness and Response Lessons from the H1N12 Influenza of 2009 by Harvey Fineberg, M.D, Ph.D (2015). Fineberg catalogs the vulnerabilities in global, national, and public capacities. These limitations fall in categories of scientific knowledge, decisionmaking under conditions of uncertainty, complexities of international operations, and communication between experts, policymakers, and the public.

Fineberg's findings support better antiviral agents, upgraded production capacity, a universal vaccine, technology-based search patterns for quicker identification and prediction, improved planning, ready reserves, and a financial 
credit line for public health implementation. These findings were confirmed in a second study by Maria D Vankerkhove and Neil M Furgeson in "Epidemic and Intervention Modeling A Scientific Rationale for Policy Decisions Lessons from the 2009 Influenza Pandemic" (2012). They affirm that better surveillance, pattern identification and precision are needed. Also, communication between policymakers and modeling groups needs further improvement, as shared data and analysis are crucial for informed decisions. The findings in these two articles relate to my project in that they outline suggestions intended to improve outcomes from the pandemic in 2009 to future pandemics such as COVID-19. I will be evaluating the medical response to Covid-19 in Vernonia, a community with a pandemic preparedness plan.

In the peer-reviewed article "Differences in Preventive Behaviours of COVID-19 between Urban and Rural Residents: Lessons Learned from a CrossSectional Study in China" by Xuewei Chen and Hongliang Chen, the differences in preventative behaviors between urban and rural residents regarding COVID-19 are examined (2020). They identify factors that contribute to disparities. They found rural residents were less likely to perform preventive behaviors and more likely to hold a negative attitude towards the effectiveness of behavioral changes. Also, rural residents are more likely to have lower levels of information appraisal skills compounded by access to credible information sources. They suggest tailoring information to meet the rural population's unique needs to impact behavioral change effectively. As urban areas are inundated with COVID-19, rural residents see themselves as unaffected because it is underrepresented in the media. So, public health efforts need to make targeted messaging. This article discusses rural information pipeline deficits and the role they play in health outcomes. I will see if this issue had any bearing on the medical delivery system in Vernonia, Oregon.

\section{Methods:}

The primary research method for this project is individual interviews. A literature review focused on the lessons learned from the H1N1 epidemic as the basis for the pandemic preparedness plan adopted by Columbia County. It also addressed discrepancies in rural and urban behavior regarding Covid-19. The review helped formulate questions for the individual interviews. This paper will detail any movement toward mitigating issues identified in the literature and any issues self-identified by interviewees for future consideration. The interview stage consisted of identifying individuals who either directly contributed to the development of the Columbia County plan, played a direct role in implementing this plan, or were directly affected by this plan's success or failures. For the purpose of privacy, the interviewees in this project are identified by pseudonyms and are as follows: a Public Health Emergency Preparedness Coordinator, who 
here is identified by the pseudonym Betty Thompsom [BT]; an independent medical provider, who here is identified by the pseudonym Darcy Clint [DC]; a medical board member, who here is identified by the pseudonym Joan Cassidy [JC]; Director of Clinical Services at a primary care rural health clinic, who here is identified by the pseudonym Jane Smith [JS]; and a physical therapist, who here is identified by the pseudonym John Doe [JD].

The interview questions reviewed the efficacy of the preparedness plan, the impact on the business model, impact on medical access, communication pathways, hurdles navigated, and new solutions identified. Interviews were conducted over a one-week period. Participants were sent questions in advance. Observing safety guidelines due to COVID-19, interviews were completed over the phone and recorded with participants' knowledge. Participants were informed that the final report would use pseudonyms and that they and their place of business would not be directly identified with every effort taken to maintain anonymity. It was acknowledged that anonymity was not guaranteed due to location, sample size, and proximity of participants relative to each other. All participants agreed to these parameters. Follow-up questions were gathered via email correspondence. Recordings and follow-up responses were transcribed, and then recordings will be deleted upon completion of this project. This project was conducted between October 2020 to December 2020.

\section{Data Analysis and Findings:}

This project's data analysis methods consisted of reading the transcripts and coding them into categories. Six categories were generated from the data: Preparedness, Government Intervention, Economic Impact on Business, Business Responsivity, Community Impact, and Future Goals. For a brief summary of the data analysis, see the Appendix.

\section{Preparedness}

In the first category of Preparedness, respondents reflected whether or not they had a policy in place before COVID and the impact of the personal protective equipment (PPE) shortage. Answers varied 50/50 regarding whether or not a policy had been in place prior to COVID. Yet even those who had a policy in place stated that it was not sufficient to meet the needs initially. Respondent [JC] states:

My board had in place regulations that mitigate communicable and infectious disease transmission that I must be in compliance with. All of those protocols were exceeded by my business policies. So, there was planning in place... My policies have always exceeded recommendations... [For instance] when a patient is unmasked and in the 
face cradle, the droplets from exhalation land on the adjusting mechanism. There is no way to adequately disinfect without submersion of 30-minute UVC light, in my opinion... This was one of my factors to refer my patients out.

Respondent [JS] noted that they could evolve their policy to meet their client base's needs:

We were not as prepared as we could have been. We do have a pandemic response policy. However, we definitely learned some new things during this pandemic and we have come up with some really creative ideas. So, we actually did a great job with it, I feel. We did have a pandemic policy in place.

Regarding the PPE shortage, only one respondent felt that they had been adversely affected by the PPE shortage. Other respondents had been able to utilize the shutdown period to either stock up on supplies or participate in government procurement opportunities. Participant [JS] found the shortage to have an adverse impact:

That was a tough one. We really had a shortage of certain PPE. For a while we were needing to reuse N 95 masks, but they are intended for a one time use but because of the national shortage, we had no other option. Since then, things have gotten better, it made us more flexible and resourceful.

Other respondents concurred that they had been able to procure adequate supplies by the time they were back in direct patient contact. [JD] notes:

It wasn't a huge deal because we were closed those first six weeks. This allowed us to purchase supplies, and in this timeframe, they determined patients could wear their own cloth masks. So, we were able to keep N- 95 for employees.

Overall, medical providers felt unprepared but were able to use the sixweek shutdown to procure needed supplies and review and evolve policies.

\section{Government Interventions}

The category of Government Interventions reveals how business models were affected by Governor Brown's mandate 20-12 and whether or not they were able to participate in any government programs or funding opportunities. Answers 
varied as to how they were affected by the governor's mandate, but all reported it had some impact on their business model. All but one were initially closed for a minimum of six weeks, and all had to restructure either the number of patients they saw or the manner in which they saw them. Participant [JS] did not have to close down:

This had a really big impact because we had to limit the amount of patients we could see within our clinics, and we have little health clinics. So, we are really serving underserved community members of all ages. It was really impactful in that we had to limit the amount of people we could have coming in and how many people could be with them. It cut our patient volumes in half if not more. It was really big hit financially... We could not do certain procedures or exams.

Even respondents that initially closed down reported having to make business model changes that impacted their patient load as a direct response to the governor's mandate. [DC] notes:

Well, definitely has cut down my patient load. I don't allow people to linger in the waiting room. I have to sanitize prior to people coming into the office, and in between each patient... So, now I see one patient at a time, everything is separated.

All but one interviewee was able to find a program or funding opportunity that supported them through some of the fiscal impacts due to business model changes necessitated by the response to COVID-19. Through the C.A.R.E.S Act, these programs included the Payroll Protection Program (PPP), POVAK Grant, grants through the state or county that were funded by CARES dollars, Oregon Health Authority (OHA) grant for supplies, and a Columbia County Small Business Grant. This funding helped these business models adapt and continue to provide services to clients without which may not have been possible. As reported by $[\mathrm{JS}]$ :

Yes, we received federal funding and worked with Oregon Health Authority for PPE supplies and testing equipment. We were able to get a POVAK grant. If funding was not available, then it would have taken longer to get COVID tests, less access locations, decrease in community's health and wellness. 
The one participant unable to procure federal support found that not all business models were included in all federal funding opportunities. [JC] notes: "It turned out I could not meet the criteria."

\section{Economic Impacts on Business}

The next category of Economic Impacts on Business reveals that it was not just the mandated shutdown that impacted the business fiscally. Increased unemployment and loss of insurance had a direct economic impact on business models. This was because people could not pay their bills, resulting in write-offs or canceled appointments. Respondent [JS] reports: "We took a financial hit because we wrote things off, and we offered more financial assistance but because our mission is to meet people where they are at financially." And [DC] reports: "It has I have definitely heard people that have just stopped coming in because they can't afford to come in that they have no coverage."

A second impact on business' financial stability was that many clients delayed seeking services, either because they feared contracting COVID-19 or services had been deemed elective. Declaring certain services elective resulted in a decrease in referrals. [JD] notes: "Yes, one good example is that elective surgeries were delayed, and so we had clients that had hit a plateau, and we couldn't see them until after surgery." And [JS] notes: "Yes, people were so worried about COVID waiting for hours for COVID tests. If they cannot find what they need in time, then they will feel that they need to try and find somewhere else."

In the categories of Government Intervention and Economic Impacts on Businesses, the medical delivery system was limited in the number of patients and types of procedures, which directly impacted patients' ability to access services. This in turn resulted in loss of revenue that government programs attempted to offset. These programs reflect the government's recognition that their mandates would have a fiscal impact. However, the findings bear out that while broad in scope, the funding programs were not all-encompassing for all medical providers to be able to participate. The inability to access offset funding had a negative impact on at least one practitioner's business model.

\section{Business Responsivity}

The next category of Business Responsivity includes how businesses could evolve their business model or expand existing programs to meet patients' needs and stabilize their business model. All respondents agreed that preparedness policies and general operational policies need to be a living document and evolve in a timely manner. This evolution spans a spectrum where some businesses can respond in real-time while others have a corporate structure or exist in a shared space requiring a more involved process. [JD] has both a stand-alone office in a 
different city and shared space in this rural setting and describes the difference between how policy changes are made:

"In Portland we are a stand-alone clinic and in Vernonia we rent space in the medical clinic. So, we have to be careful that our policies are not conflict in a shared space but still maintain the safety of our staff and patients that are moving through a space where other providers are seeing patients that may be sick. So that has been a major difference."

The response from [JS], on the other hand, notes having to be mindful of their corporate structure: "We are required to follow corporate policies however they coincide with the state level so we are following all of the things that are state and corporate mandated."

Technology also played a role in business responsiveness. Some business models had the infrastructure to participate in telemedicine, but since COVID -19 revealed the benefit, they have expanded this program. Other practitioners had not been able to participate in telemedicine previously. Their respective boards made new emergency allowances for them to utilize this technology and bill for reimbursement. All agree that this has been a positive outcome and hope telemedicine continues after the pandemic is resolved. [DC] notes:

"Yes, definitely doing some telemedicine and being able to keep up with shuffling documents for example I had patients who had to go to the ER but now we have useful electronic facts and things like that so I can see what's going on with my patients so that when I'm on the phone having a teleconference I can see what's going on there."

Respondent [JD] details out the benefit to patient care for it to continue and why:

Physical Therapy as a profession has always been excited for and pushed for telemedicine as something to be included as a covered service through insurance that we could perform and insurance would reimburse us for it. However, they always said that it was not and thus would not pay for it. Then COVID-19 hit and almost all insurances lifted their restriction on telemedicine for PT. Now we can see and treat people through telemedicine and insurance will reimburse us for it. However, all of these insurances have a "sunsetting" clause in the arrangement. When the pandemic started they said that PT telemedicine would be covered until May. When we saw that the pandemic was going to last longer than that they pushed it back to December 2020. I anticipate that they will push it back again since we're still in the thick of things, but the problem with that is we never know if telemedicine will be a continued covered service moving forward. If it is, then we could really push to get care to many 
rural cities and towns in the United States to help people who have never had the opportunity to have care.

\section{Community Impact}

Participants also disclosed how the impact of COVID-19 on their business model required changes in how they engage with the community. The category of Community Impact indicates new communication methods with patients. All respondents shared how they are using multiple mediums for communication including technology expansions, enhanced email and patient portals, new informational signage, posters, reader boards, telemedicine, reverse 911 calls and mailers for mass communication, website updates, and even phone apps and social media. [BT] emphasizes it is not only the modality but the consistency of the messaging that is important. Messaging needs to not only educate but serve to mitigate economic, literacy, and cultural disparities:

Input from partners and stakeholders is imperative to this process down to not only the messaging modality but does the message meet the literacy, cultural, and Accessibility threshold... Every County has a rural component but we have some parts that are even considered frontier one of the biggest lessons we learned in H1N1 was that trust was vital. The community needs to trust if public health is to have any hope of success. Like when getting out the vaccine for H1N1 the amount of a compliance was directly linked to the level of trust which led back to consistency and data-driven messaging that was easily understandable.

The importance of information communication is supported by the findings of Chen and Chen (2020):

... [we] suggest tailoring information to meet the rural population's unique needs to effectively impact behavioral change. As urban areas are inundated with COVID-19 rural residents see themselves as unaffected because it is underrepresented in the media. So Public Health efforts need to make targeted messaging.

This section also revealed the value these businesses contribute to the community for both practitioners and their clients. All practitioners agree that local, timely access to medical services contributes directly to positive outcomes for patients. [JC] states: 
For a community our size it is imperative that patients have local direct access to maintain and manage their health. It is a foundational cornerstone that respects both their health and dignity, and promotes autonomy. When barriers to healthcare are not recognized or addressed by our leaders it sends the message that those communities have no value.

Also in agreement, [JS] states: “... without us here some patients would not be doing as well as they are doing now. It would have been a huge impact there would be delayed care."

\section{Future Goals}

When asked about lessons learned or future goals all respondents agreed that telemedicine has been identified as a positive development, and capacity needs to be expanded. This new technology cannot reach all of the client base in this area due to failing or inadequate infrastructure. Every respondent recognizes the need for upgrades to internet service and/or cellular services. [BT] weaves this theme through many of her answers:

One example of new administrations in this part of the plan would be cell phones, texting, social media but also recognizing this could be a barrier...

Expand access to health care, telehealth, reach more people, broadband internet service to all our residents, cell service both increased access and increased reliability. In a public health crisis those two things, access to health care and reliable communication. In rural areas timely information and communication is, well how do we accomplish that without internet or texting.

While almost as an afterthought, [JC] proposed for future planning consideration employee burnout:

But you know one thing that is not included in your questions, and probably because it was not included in the planning, is the cost of staff burnout. It is huge to mitigate having to practice in an evolving reality! Not only are providers having to alter their whole paradigm they have to manage the stress of patients that are either in denial or not coping well with isolation that this has manifested into. 
The final categories of Business Responsivity and Future Goals show the vital role technology plays in health education, provider-patient communication, and medical service accessibility. Without the basic infrastructure in place for technology during the pandemic, the resulting impact would have been more significant. All providers agree that continued expansion and improvements to this infrastructure need to continue.

\section{Conclusion and Critical Reflexivity:}

In conclusion, even the participants with a pandemic policy under the Columbia County model prior to COVID-19 found that it was insufficient. All agreed on the need to remain flexible in order to update policies in a timely and responsive manner. Government interventions were imperative in supporting the sustainability of their medical business models and providing continuity of care to patients. This came not only in grant opportunities but regulatory measures taken to expand billable services. We can observe that businesses ineligible for these programs were adversely affected up to and including closure. However, a larger sample size would be required to determine correlation or causation. Across the board, technology has had a positive impact. It has altered how patients are communicated with, services are provided, and even the structure of the business paradigm.

Technology is also singled out as a crucial future goal, not only to ensure connectivity of provider to patient but to potentially help remedy other identified health barriers. Internet access in this community always seemed sufficient prior to COVID-19. While it has allowed for the medical community to incorporate telemedicine into their model, participants identify insufficiency citing workfrom-home employees and local K-12 all vying for access at the same time.

As a student researcher, I recognize the identity that I have does make a difference in the information I access. For example, I am a resident of Vernonia and have been a patient of most of my interviewees. Until now, our relationship has been patient/provider. However, I chose to meet them with my studentresearcher identity. I took care to set the stage for this by an introductory email providing them information about my project, background information that I have already procured, scheduling interview appointments well in advance, and their list of interview questions. I was punctual with appointment times and followed up with thank yous and questions by email. One interviewee remarked how that changed the conversation. The information they would have given to patients would have been prepared and perfunctory. Because I was a student-researcher, our conversation was both deeper and broader. My commitment to asserting myself professionally was met in kind with no perceived power imbalances. The interviewees were open and did not respond adversely to my age or gender. I felt 
interviewees were forthright and transparent, and I provided full disclosure regarding the parameters around my project.

This study revealed nuanced but common experiences on how COVID-19 impacts a rural medical delivery system. However, in order to bear any weight, this research would need to be done in multiple rural communities to determine if this experience holds true or if each community has its own set of challenges unique to themselves. The contributing factors may include geographic barriers, economic disparities, cultural disparities, population variances, and provider access. Any one or a combination of these elements could influence these findings. It would be of value to do further research on the plausibility and impact of upgraded and reliable technology infrastructure on medical delivery systems in rural communities.

\section{References}

Adventist Health Systems. (2020). "Coronavirus (COVID-19) Preparedness." Adventist Health. https://www.adventisthealth.org/coronaviruspreparedness/.

Brown, K. (2020). "Executive Order 20-12.” State of Oregon: Administration Executive Order 20-12, 2020. https://www.oregon.gov/gov/admin/Pages/eo_20-12.aspx.

Chen, X. \& Chen, H. (2020). Differences in Preventive Behaviors of COVID-19 between Urban and Rural Residents: Lessons Learned from A CrossSectional Study in China. International Journal of Environmental Research and Public Health, 17(12), 4437.

City of Vernonia. (2014) Flood Info. https:/www.vernonia-or.gov/flood/. Columbia County, Oregon. (2020) Coronavirus Disease 2019. https://www.columbiacountyor.gov/departments/PublicHealth/Coronaviru sDisease2019COVID19.

Columbia County Economic Team. (2020) COVID-19. https://smallbizhub.columbiacountyoregon.com/.

Crenshaw, A. (2008). Vernonia Flood Recovery. https://www.youtube.com/watch?v=3SdxH4HYi5c\&ab_channel=Andrea Crenshaw

Fineburg, H.(2014). Pandemic Preparedness and Response - Lessons from the H1N1 Influenza of 2009. The New England Journal of Medicine 372(2), https://www.nejm.org/doi/pdf/10.1056/NEJMra1208802

Office of Disease Prevention and Health Promotion. (2020) Access to Health Services. https://www.healthypeople.gov/2020/topicsobjectives/topic/Access-to-Health-Services. 
Office, U.S. Government Accountability. (2011) Influenza Pandemic: Lessons from the H1N1 Pandemic Should Be Incorporated into Future Planning https://www.gao.gov/products/GAO-11-632.

Office of Rural Health. (2020) Maps. https://www.ohsu.edu/media/106491.

Oregon Health Authority. (2020). COVID-19 Weekly Report. www.oregon.gov/oha/PH/DISEASESCONDITIONS/DISEASESAZ/Emer ging\%20Respitory\%20Infections/COVID-19-Weekly-Report-2020-05-19FINAL.pdf?fbclid=IwAR3TXODgup90vDC0kJ6vizlmPSKjgsW5aaIaRWa1Tsd0ibgz06Y01Bq VY.

Oregon Health Authority. (2020) COVID-19 Updates. https://govstatus.egov.com/OR-OHA-COVID-19.

Oregon Solutions. (2008). Catalyst The Campaign for Vernonia's Schools. http://orsolutions.org/wp-content/uploads/2011/08/VSD Case 4pp.pdf.

Van Kerkhove, M., \& Ferguson, N. (2012). Epidemic and Intervention Modelling - a Scientific Rationale for Policy Decisions? Lessons from the 2009 Influenza Pandemic. Bulletin of the World Health Organization 90(4), 306-10. 


\section{Appendix}

Data Analysis Matrix

\begin{tabular}{|c|c|c|c|c|c|}
\hline $\begin{array}{l}\text { Interview } \\
\text { Matrix }\end{array}$ & $\begin{array}{l}\text { Physical } \\
\text { Therapist } \\
\text { [J.D] }\end{array}$ & $\begin{array}{l}\text { Primary } \\
\text { Care } \\
\text { Rural } \\
\text { Health } \\
\text { Clinic } \\
\text { Director } \\
\text { [J.S] }\end{array}$ & $\begin{array}{l}\text { Ancillary } \\
\text { Services } \\
\text { [J.C] }\end{array}$ & 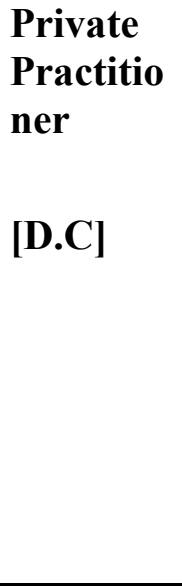 & $\begin{array}{l}\text { Columbia } \\
\text { County } \\
\text { Public } \\
\text { Health } \\
\text { Emergenc } \\
\text { y } \\
\text { Prepared } \\
\text { ness } \\
\text { Coordina } \\
\text { tor } \\
\text { [B.T] }\end{array}$ \\
\hline $\begin{array}{l}\text { Preparedn } \\
\text { ess } \\
\text { Pandemic } \\
\text { Response } \\
\text { Policy in } \\
\text { place prior } \\
\text { to COVID? }\end{array}$ & $\begin{array}{l}\text { No, any } \\
\text { policy we } \\
\text { had was } \\
\text { outdated. }\end{array}$ & $\begin{array}{l}\text { Yes, the } \\
\text { policy } \\
\text { was in } \\
\text { place. } \\
\text { Not as } \\
\text { prepared } \\
\text { as we } \\
\text { could } \\
\text { have } \\
\text { been. }\end{array}$ & $\begin{array}{l}\text { Yes, } \\
\text { protocols } \\
\text { were in } \\
\text { place but } \\
\text { did not } \\
\text { meet the } \\
\text { needs of } \\
\text { my client } \\
\text { base. }\end{array}$ & $\begin{array}{l}\text { No, I did } \\
\text { not have } \\
\text { a } \\
\text { pandemic } \\
\text { policy in } \\
\text { place. }\end{array}$ & $\begin{array}{l}\text { Yes, } \\
\text { policy in } \\
\text { place. } \\
\text { Working } \\
\text { on it since } \\
2009 \text {. }\end{array}$ \\
\hline $\begin{array}{l}\text { PPE } \\
\text { shortage } \\
\text { impact? }\end{array}$ & $\begin{array}{l}\text { No, able to } \\
\text { stock up } \\
\text { during the } \\
\text { close- } \\
\text { down }\end{array}$ & $\begin{array}{l}\text { Yes, had } \\
\text { to be } \\
\text { flexible } \\
\text { and } \\
\text { resourcef } \\
\text { ul. }\end{array}$ & $\begin{array}{l}\text { No, the } \\
\text { business } \\
\text { closed }\end{array}$ & $\begin{array}{l}\text { No, able } \\
\text { to stock } \\
\text { up during } \\
\text { the close- } \\
\text { down }\end{array}$ & $\begin{array}{l}\text { After } \\
\text { initial } \\
\text { delay able } \\
\text { to provide } \\
\text { other } \\
\text { business } \\
\text { with PPE. } \\
\text { * }\end{array}$ \\
\hline
\end{tabular}




\begin{tabular}{|c|c|c|c|c|c|}
\hline $\begin{array}{l}\text { Governme } \\
\text { nt } \\
\text { Interventio } \\
\text { ns } \\
\text { Affected By } \\
\text { Gov's } \\
\text { mandate }\end{array}$ & $\begin{array}{l}\text { Closed for } \\
6 \text { weeks. } \\
\text { Reduced } \\
\text { patient } \\
\text { load. } \\
\text { Patient and } \\
\text { fiscal } \\
\text { impact. }\end{array}$ & $\begin{array}{l}\text { Had to } \\
\text { limit the } \\
\text { number } \\
\text { of } \\
\text { patients } \\
\text { we could } \\
\text { see. } \\
\text { Patient } \\
\text { and fiscal } \\
\text { impact. }\end{array}$ & $\begin{array}{l}\text { Business } \\
\text { closed. } \\
\text { Referred } \\
\text { patients } \\
\text { out. } \\
\text { Patient and } \\
\text { fiscal } \\
\text { impact. }\end{array}$ & $\begin{array}{l}\text { Initially } \\
\text { closed, } \\
\text { now } \\
\text { limits } \\
\text { patient } \\
\text { load. } \\
\text { Patient } \\
\text { and fiscal } \\
\text { impact. }\end{array}$ & $\begin{array}{l}\text { Expanded } \\
\text { reporting } \\
\text { requireme } \\
\text { nts. } \\
\text { Additional } \\
\text { burden to } \\
\text { staff. }\end{array}$ \\
\hline
\end{tabular}

\begin{tabular}{|c|c|c|c|c|c|}
\hline $\begin{array}{l}\text { Participatio } \\
\mathrm{n} \text { in gov't } \\
\text { programs }\end{array}$ & $\begin{array}{l}\text { Yes, } \\
\text { P.P.P. }\end{array}$ & $\begin{array}{l}\text { Yes, PPP, } \\
\text { POVAK } \\
\text { Grant's, } \\
\text { and OHA } \\
\text { Grant for } \\
\text { supplies } \\
\text { and } \\
\text { testing } \\
\text { equipment } \\
\text {. }\end{array}$ & $\begin{array}{l}\text { No, did } \\
\text { not fit the } \\
\text { criteria. }\end{array}$ & $\begin{array}{l}\text { Yes, } \\
\text { Columbia } \\
\text { County } \\
\text { Small } \\
\text { Business } \\
\text { Grant. } \\
\text { Not } \\
\text { eligible } \\
\text { for } \\
\text { federal } \\
\text { grant. }\end{array}$ & $\begin{array}{l}\text { Yes, } \\
\text { received } \\
\text { CARES } \\
\text { Act } \\
\text { funding. }\end{array}$ \\
\hline $\begin{array}{l}\text { Economic } \\
\text { Impacts on } \\
\text { Business } \\
\text { Increased } \\
\text { unemploym } \\
\text { ent effects } \\
\text { on payor } \\
\text { mix }\end{array}$ & $\begin{array}{l}\text { Referred } \\
\text { them to } \\
\text { apply for } \\
\text { OHP. }\end{array}$ & $\begin{array}{l}\text { Yes, } \\
\text { financial } \\
\text { impact, } \\
\text { increased } \\
\text { write-offs. }\end{array}$ & $\begin{array}{l}\text { Yes, } \\
\text { Business } \\
\text { closed. }\end{array}$ & $\begin{array}{l}\text { Yes, } \\
\text { decreased } \\
\text { clients } \\
\text { due to } \\
\text { financial } \\
\text { hardships. }\end{array}$ & N/A \\
\hline $\begin{array}{l}\text { COVID-19 } \\
\text { cause delay } \\
\text { in clients } \\
\text { seeking } \\
\text { services }\end{array}$ & $\begin{array}{l}\text { Yes, } \\
\text { elective } \\
\text { procedures } \\
\text { delayed. } \\
\text { Decrease } \\
\text { in } \\
\text { referrals. }\end{array}$ & $\begin{array}{l}\text { Yes, } \\
\text { people } \\
\text { worried } \\
\text { about } \\
\text { COVID- } \\
19,\end{array}$ & $\begin{array}{l}\text { Business } \\
\text { Closed. } \\
\text { Patients } \\
\text { referred } \\
\text { out. }\end{array}$ & $\begin{array}{l}\text { Yes, } \\
\text { initially } \\
\text { from fear } \\
\text { con } \\
\text { contractin } \\
\text { g }\end{array}$ & N/A \\
\hline
\end{tabular}




\begin{tabular}{|c|c|c|c|c|c|}
\hline & & $\begin{array}{l}\text { postponed } \\
\text { appointme } \\
\text { nts }\end{array}$ & & $\begin{array}{l}\text { COVID- } \\
19 .\end{array}$ & \\
\hline 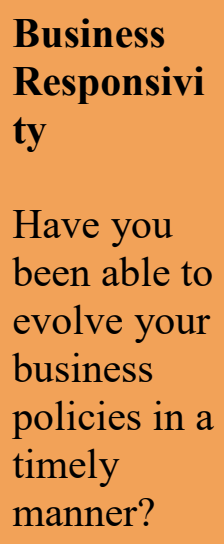 & $\begin{array}{l}\text { Policy } \\
\text { evolves to } \\
\text { meet } \\
\text { regulation } \\
\text { s and } \\
\text { patient } \\
\text { needs. }\end{array}$ & $\begin{array}{l}\text { Policy } \\
\text { evolves as } \\
\text { state and } \\
\text { corporate } \\
\text { model } \\
\text { mandate. }\end{array}$ & $\begin{array}{l}\text { Policy will } \\
\text { be } \\
\text { evaluated } \\
\text { when the } \\
\text { business } \\
\text { re- opens. }\end{array}$ & $\begin{array}{l}\text { Yes, } \\
\text { policy } \\
\text { evolves to } \\
\text { comply } \\
\text { with } \\
\text { regulation } \\
\text { s and } \\
\text { patient } \\
\text { needs. }\end{array}$ & N/A \\
\hline $\begin{array}{l}\text { Technology } \\
\text { role during } \\
\text { COVID- } 19\end{array}$ & $\begin{array}{l}\text { State } \\
\text { board now } \\
\text { allows } \\
\text { telemedici } \\
\text { ne.* } \\
\text { NEW }\end{array}$ & $\begin{array}{l}\text { Yes, we } \\
\text { have } \\
\text { expanded } \\
\text { our } \\
\text { telemedici } \\
\text { ne. }\end{array}$ & $\begin{array}{l}\text { Phone } \\
\text { consults. } \\
\text { Unreimbur } \\
\text { sed }\end{array}$ & $\begin{array}{l}\text { Yes, } \\
\text { introduce } \\
\text { d } \\
\text { telemedic } \\
\text { ine. } \\
\text { NEW }\end{array}$ & $\mathrm{N} / \mathrm{A}$ \\
\hline $\begin{array}{l}\text { Communit } \\
\text { y Impact } \\
\text { Communica } \\
\text { tion }\end{array}$ & $\begin{array}{l}\text { Patient } \\
\text { portal, } \\
\text { lobby } \\
\text { informatio } \\
\text { nal } \\
\text { posters. }\end{array}$ & $\begin{array}{l}\text { Patient } \\
\text { portal, } \\
\text { home } \\
\text { visits, } \\
\text { parking } \\
\text { lot visits, } \\
\text { reader }\end{array}$ & $\begin{array}{l}\text { Phone, } \\
\text { email, and } \\
\text { patient } \\
\text { flyers. }\end{array}$ & $\begin{array}{l}\text { Phone } \\
\text { call, } \\
\text { email, } \\
\text { home } \\
\text { visits, and } \\
\text { signage. }\end{array}$ & $\begin{array}{l}\text { Utilized } \\
\text { reverse } \\
911 \text { call } \\
\text { and } \\
\text { website }\end{array}$ \\
\hline
\end{tabular}

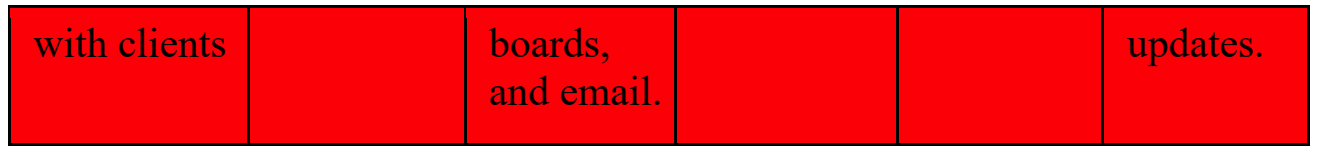




\begin{tabular}{|c|c|c|c|c|c|}
\hline $\begin{array}{l}\text { Value to the } \\
\text { community }\end{array}$ & $\begin{array}{l}\text { Accurate } \\
\text { informatio } \\
\mathrm{n} \text { and an } \\
\text { access } \\
\text { point. }\end{array}$ & $\begin{array}{l}\text { Local, } \\
\text { timely } \\
\text { access. }\end{array}$ & $\begin{array}{l}\text { Local } \\
\text { access. }\end{array}$ & $\begin{array}{l}\text { Local, } \\
\text { timely } \\
\text { access. }\end{array}$ & $\begin{array}{l}\text { Find and } \\
\text { plug the } \\
\text { holes in } \\
\text { the } \\
\text { system so } \\
\text { local } \\
\text { providers } \\
\text { can } \\
\text { remain } \\
\text { sustainabl } \\
\text { e. }\end{array}$ \\
\hline $\begin{array}{l}\text { Future } \\
\text { Goals } \\
\text { Telemedici } \\
\text { ne }\end{array}$ & Continue & Continue & N/A & Continue & N/A \\
\hline \multirow{2}{*}{$\begin{array}{l}\text { Connectivit } \\
\text { y } \\
\text { Infrastructu } \\
\text { re }\end{array}$} & $\begin{array}{l}\text { Needs } \\
\text { Improvem } \\
\text { ent }\end{array}$ & $\begin{array}{l}\text { Needs } \\
\text { Improvem } \\
\text { ent }\end{array}$ & $\begin{array}{l}\text { Needs } \\
\text { Improvem } \\
\text { ent }\end{array}$ & $\begin{array}{l}\text { Needs } \\
\text { Improve } \\
\text { ment }\end{array}$ & $\begin{array}{l}\text { Needs } \\
\text { Improve } \\
\text { ment }\end{array}$ \\
\hline & $\begin{array}{l}\text { Cell and } \\
\text { Internet }\end{array}$ & $\begin{array}{l}\text { Cell and } \\
\text { Internet }\end{array}$ & $\begin{array}{l}\text { Cell and } \\
\text { Internet }\end{array}$ & $\begin{array}{l}\text { Cell and } \\
\text { Internet }\end{array}$ & $\begin{array}{l}\text { Cell and } \\
\text { Internet }\end{array}$ \\
\hline $\begin{array}{l}\text { Planning } \\
\text { for }\end{array}$ & Impacted & Impacted & $\begin{array}{l}\text { Human } \\
\text { cost }\end{array}$ & Impacted & N/A \\
\hline \multirow[t]{3}{*}{$\begin{array}{l}\text { Staff } \\
\text { Burnout }\end{array}$} & & & not & & \\
\hline & & & $\begin{array}{l}\text { compensat } \\
\text { ed }\end{array}$ & & \\
\hline & & & $\begin{array}{l}\text { for } \\
\text { adequately }\end{array}$ & & \\
\hline
\end{tabular}

*indicates information also considered a government intervention 